\title{
Selected Reference Books of 1972-73
}

\section{INTRODUCTION}

$\mathrm{T}$ HIS ARTICle CONTINUES the semiannual series originally edited by Constance M. Winchell. Although it appears under a byline, the list is actually a project of the Reference Department of the Columbia University Libraries, and notes are signed with the initials of the individual staff members. ${ }^{1}$

In the past, mention in this column of supplements and new editions has been the exception rather than the rule. A departure from that practice is made in this issue, and a brief roundup of such items is presented at the end of the column.

Since the purpose of the list is to present a selection of recent scholarly and foreign works of interest to reference workers in university libraries, it does not pretend to be either well balanced or comprehensive. Code numbers (such as AA71, 2BD89) have been used to refer to titles in the Guide to Reference Books and its supplements. ${ }^{2}$

\section{BIBLIOGRAPHY}

Gaskell, Philip. A New Introduction to Bibliography. N.Y., Oxford Univ. Pr.; Oxford, Clarendon Pr., 1972. 438p. il. $\$ 9.50$. 73-153680.

An important achievement, this book

1. Diane Goon, Rita Keckeissen, Eileen McIlvaine, Mary Ann Miller, Nancy Schroeder, Doris Ann Sweet, Barbara Wendell; School of Library Service, Evelyn Lauer; School of International Affairs, Janet Schneider.

2. Constance M. Winchell, Guide to Reference Books (8th ed.; Chicago: ALA, 1967); Supplement I (Chicago: ALA, 1968); Supplement II (Chicago: ALA, 1970); Supplement III (Chicago: ALA, 1972). both updates and extends the period of coverage of Ronald B. McKerrow's 1928 classic in the field of bibliographical studies, $A n$ Introduction to Bibliography for Literary Students (Guide AA4). Entirely new, not simply a revision of McKerrow, the volume describes methods of book production and distribution from the early years of printing to the middle of the twentieth century. Divided into two major sections, the handpress period (1500-1800) and the machinepress period (1800-1950) - the latter not covered by McKerrow-it includes information on type, composition, printing practices, and the book trade, as well as topics peculiar to each period. The last section of the book demonstrates applications in bibliographical description and studies on the transmission of texts. Incorporating scholarship of the forty years since McKerrow's work in this relatively young field of descriptive and historical bibliography, Gaskell does an admirable job of conveying the information clearly and in a well organized form. Extensive bibliographies (more nearly bibliographic essays) at the end of the volume make it an even more valuable reference tool.-D.A.S.

\section{NATIONAL BibLiography}

Répertoire des livres de langue française disponibles, 1972- . [Paris], FranceExpansion, [1972- ]. 2v. $\$ 80.00$. (Distr. in U.S. by Bowker.) 72-626991.

Cover title: Répertoire des livres disponibles.

Contents: v.1, Auteurs; v.2, Titres.

Here is a welcome addition to the booksin-print shelf of the large library, especially since the Catalogue de l'édition française (first published for 1970) will next cover 1973. The aim is to record all French language in-print trade books regardless of country of origin. This first issue, however, includes, in addition to the output of 
French publishers, only those foreign books that are distributed in France. Future editions are to be more inclusive. Also listed are the foreign language publications of francophone publishers.

Volume 1 is an alphabetic arrangement by author, with very full bibliographic details; volume 2 entries, by title, are somewhat shorter. Two long lists, one of publishers' series and the other of publishers' names and addresses, are appended to the first volume. A third section of the work, "un volume analytique," is promised and presumably will be a subject index to the more than 100,000 books included.-R.K.

\section{Archives}

Grimsted, Patricia Kennedy. Archives and Manuscript Repositories in the USSR: Moscow and Leningrad. Princeton, Princeton Univ. Pr., [1972]. 436p. \$22.50. 73-166375.

This directory-bibliography, addressed primarily to "the foreigner planning research in the Soviet Union" (Pref.), will appeal also to others interested in the history of Russian archives and the location of manuscripts, and surely to the librarian responsible for maintaining a reference collection on such materials.

Preliminary sections cover the history and organization of Soviet archives and such procedural information as access and research conditions. The bulk of the work is a series of descriptions of important manuscript repositories, together with valuable annotated bibliographies of the finding aids (both books and articles) pertaining to them. Six sections cover: the Central State Archives; archival collections of the Academy of Sciences; special archives such as those of the Communist Party and Foreign Ministry; manuscript divisions of libraries and museums of Moscow and of Leningrad; and republic and local state archives. There is also a long, annotated bibliography of general archival and research aids. Full bibliographical information for entries (with locations and class numbers at $\mathrm{Li}$ brary of Congress and/or Harvard), a useful glossary, a list of abbreviations used, author/title and subject indexes all add to ease of use and reference value.-R.K.

\section{FoUNDATIONS}

Foundation Center, New York. Information Quarterly, v.1, no.1- , Oct. 1972. N.Y., The Center, 1972- . Quarterly. $\$ 7.50$ per yr.

Assuming that the two issues thus far received are typical, this new quarterly will offer effective updating, on a continuing basis, of the listings in the fourth edition of the Foundation Directory. The bulk of each issue is devoted to new or revised information on 600 to 650 foundations, including descriptions of a few not appearing in the fourth edition of the Directory. Entries follow the geographical arrangement of that work (with a page reference to the fourth edition given), and provide "more recent financial data, including information on the range in size of grants, as well as other significant changes relating to address, purpose and activities, and officers." Each issue is to carry a cumulative index of foundations for which updated information has been reported in the Quarterly. The first number leads off with an informative article entitled "What Will a Foundation Look for When You Submit a Grant Proposal?"E.S.

\section{DictionaRIES}

Dupré, Paul, Encyclopédie du bon français dans l'usage contemporain: difficultés, subtilités, complexités, singularités. Paris, Editions de Trévise, [1972]. 3v. $140 \mathrm{~F}$. per v. 72-339663.

This is a dictionary of about 10,000 words which, for reasons of pronunciation, usage, gender, spelling, or foreign origin, pose problems even to educated native speakers of French. Each entry presents the opinions of one or more of five major French dictionaries, and supplements these, if necessary, with citations from grammarians, thus saving the reader a time-consuming search through many sources for the information he needs. Where disagreement exists, the editors have suggested a reasonable solution, taking into account the most recent changes in the language; this commentary, however, is intended as a synthesis, not a prescription. Useful features are a lexicon of linguistic terms and a section on important dictionaries and grammarians. 
Though intended for a French-speaking public, this dictionary should be of great value to advanced students of the French language. - N.S.

Grand Larousse de la langue française en six volumes. [Sous la direction de Louis Guilbert, René Lagane et Georges Niobey] Paris, Larousse, [1971- ]. (In progress.) $99.50 \mathrm{~F}$. per v. $71-854777$.

Contents:

This dictionary is intermediate in size between the Petit Larousse (Guide AE223) and the Grand Larousse encyclopédique (Guide AD31), but unlike them is strictly a language dictionary. More inclusive and detailed than the Dictionnaire du français contemporain (Suppl. 2AE30), it gives for each entry: transcription in the International Phonetic Alphabet, etymology and date of first attestation, definitions, examples of usage (either as quotations from authors or as phrases made up by the editors), indication of level of usage, and synonyms and antonyms. It is limited to words in use in the nineteenth and twentieth centuries, and includes a generous number of current technical terms. Special features are a seventy-two-page analysis of French word formation, with tables of Greek and Latin roots and their meanings; frequency tables; and conjugation charts. Brief articles on linguistic terms such as "accent" and "alphabet" are interspersed throughout the text.

Since the above information, though well presented, is available elsewhere, the other language dictionary of comparable size, Robert's Dictionnaire alphabétique et analogique de la langue française (Guide AE226 ) with its 1970 supplement is still to be preferred: Robert is more comprehensive, as a rule more generous with examples (to which it gives full citations; Larousse gives no page references), synonyms and antonyms, and cross-references. Libraries already owning Robert will probably not find this new Larousse an essential purchase.N.S.

\section{Periodical INDEXes}

Index Expressionismus; Bibliographie der Beiträge in den Zeitschriften und Jahrbiichern des literarischen Expression- ismus, 1910-1925. Im Auftrage des Seminars für deutsche Philologie der Universität Göttingen und Zusammenarbeit mit dem Deutschen Rechenzentrum Darmstadt, hrsg. von Paul Raabe. Nendeln, Liechtenstein, Kraus-Thomson, 1972. 18v. \$800.00. 72-83540.

Contents: v.1-4, Ser.A: Alphabetischer Index; v.5-9, Ser.B: Systematischer Index; v.10-14, Ser.C: Index nach Zeitschriften; v.15-16, Ser.D: Titelregister; v.17-18, Ser.E: Gattungsregister.

One hundred periodicals and five yearbooks associated with the expressionist movement in Germany and reflecting its influence on the whole range of German culture, literature, and the arts are analyzed in this new index. A full citation to each article, poem, drama, etc. is given in Serie $A$, the alphabetical author index, and in Serie $B$, which offers a subject approach. The indexes by title (Serie D) and by genre (Serie E) give briefer information, and it is necessary to refer to the author index for the full citation. Serie $C$ is arranged by title of the periodical and offers a printout of the contents of the full run of each publication indexed, with contributions arranged alphabetically by author; the full citation is given in each entry.

While it is interesting, and occasionally useful, to have so many approaches to the contents of these publications, series C, D, and $\mathrm{E}$ seem an unnecessary luxury, if not largely an exercise in computer capabilityparticularly so in view of the liberal spacing and the repetitiousness of the entries in Serie C. (Thus, the whole of v.12 becomes an author index to Die Aktion, and virtually all of v.11 is a similar treatment of Der Sturm.) Specialist scholars will welcome the index as it stands; librarians concerned with problems of budget and space would have settled for an author-subject index in a more compact format.-E.S.

\section{BIOGRAPHY}

Bellamy, Joyce M. and Saville, John. Dictionary of Labour Biography. [London], Macmillan; [Clifton, N.J.], A. M. Kelley, [1972- ]. v.1- . (In progress) v.1, \& 10. 78-185417.

Not only national figures in the British 
labor movement, but also activists at the regional and local levels are to be included in this ambitious new biographical dictionary. Indeed, it intends to include "everyone who made a contribution, however modest, to any organisation or movement, provided that certain basic details of their career can be established."-Introd. The period of coverage is from 1790 to the present, but living persons are excluded. It is expected that fifteen to twenty volumes will be required to treat figures down to 1914 alone. Each volume will be alphabetically arranged and will include biographies without regard to date of the subject's activity. The decision to begin publication with what material was at hand has meant that $\mathrm{v} .1$ shows a predominance of miners' leaders and cooperators, since mining is the best-documented trade union field. However, the editors have tried "to include a fair selection of other types of radicals, reformers, and trade unionists." Articles are signed; sources are cited; and cross-references are provided to articles within the present volume and to names to be treated in later volumes. A consolidated index is promised for each successive volume.-E.S.

\section{RELIGION}

The Study of Judaism; Bibliographical EsB'nai B'rith, 1972. 229p. \$12.50. 72says. N.Y., Anti-Defamation League of 79129.

Not simply a list of books, this work is, rather, a collection of thoughtful essays on important problems in Jewish studies. Heightened interest in this field in many colleges and universities will make it a popular reference work, although ease of use is hampered by the essay format and lack of a subject/name index. However, the background material (though duplicated in many standard sources) along with the critical annotations and chapter arrangement will serve to give the reader a general overview of such issues as the "Holocaust" and the "Contemporary Jewish Community." In addition, almost all of the works cited are in English or one of the more common Western European languages, making this a particularly useful volume for the undergraduate or nonspecialist.-B.W.

\section{LINGUISTICS}

University of Rhodesia. Library. Catalogue of the C. M. Doke Collection on African Languages in the Library of the University of Rhodesia. Boston, G. K. Hall, 1972. 546p. $\$ 55.00$. (Its Bibliographical Ser., no.2.) 72-2074.

The distinguished linguistics scholar, lexicographer, and translator, Clement $\mathbf{M}$. Doke is perhaps most widely known for his work on Zulu-English dictionaries (Guide AE585-87), but his work in the field of African languages was wide-ranging and varied. His excellent working collection of books, pamphlets, and manuscripts "constitute the nucleus, and still the major part" (p.xvii) of the collection of more than 3,000 items represented in this catalog. A reproduction from typewritten catalog cards, the work is in two sections, authors and subjects. The subject section is arranged by Library of Congress classification, with typewritten guide cards interfiled as subject indicators. The lack of running heads and the reduction in type size make the subject section difficult to use. Surely a key to the major LC classes represented (there is a heavy concentration in PL80008844 ) could have been provided, and an alphabetical list of languages with corresponding class marks or page references would have been helpful. Doke's own works are not included in the collection, but a bibliography of his published and unpublished writings is furnished in the prefatory matter.-E.S.

\section{LITERATURE}

Contemporary Novelists. With a preface by Walter Allen. Editor: James Vinson. N.Y., St. Martin's Pr., [1972]. 1422p. $\$ 30.00$. 75-189694.

Second in the series "Contemporary Writers of the English Language" (Contemporary Poets was published in 1970 and Contemporary Dramatists is in preparation), this volume is a critical biobibliography of novelists and short story authors writing in English since 1940. The selection is based on the recommendation of an advisory board, but generally follows a definition of the novelist as the author of "a broadly realistic representation of man's 
life in society which is also a criticism of life and of society."-Pref. The format of each entry is: brief biography, bibliography (principally works by the entrant, arranged by genre), location of manuscript collections, comment by the author on his work, and a signed critical essay. Entries vary in length from two to six pages. A brief section identifies the advisers and contributors to the volume. Omissions (e.g., Kerouac, Momaday) can always be noted, but this is a useful "something-about-the-author" book, and the critical essays - often stimulating-may lead the reader to the novels themselves.-D.G.

Domandi, Agnes Körner, comp. and ed. Modern German Literature. N.Y., Ungar, [1972]. 2v. $\$ 30.00$. (A library of literary criticism.) 70-160436.

Through critical texts chosen "to convey ... something of an author's achievement and, secondarily of the critic's point of view," this work seeks to "acquaint its readers with twentieth-century German literature as seen by critics of this century."Introd. Excerpts averaging about 150 words in length deal with more than 200 authors of fiction, drama, and poetry from East and West Germany, Austria and Switzerland. Arrangement is alphabetic by author covered; the texts, drawn from British, American, and European journals, newspapers and books, appear in chronological order and carry full bibliographical information. German selections have been specially translated for this compilation. Excerpts number from four to five for lesser figures to more than thirty for well-known writers. Each section ends with a selected listing of the writer's works with publication dates for both the original and the English translation. The volume will be useful primarily for the less well-known figures and for the English translations listed.-R.K.

McGraw-Hill Encyclopedia of World Drama; an International Reference Work. N.Y., McGraw-Hill, [1972]. 4v. il. \$119.50. 70-37382.

If you were expecting a kind of Englishlanguage Enciclopedia dello spettacolo concentrating on drama, disappointment is in store. Concern here is almost exclusively with dramatists and the literature of the theater; aspects of production and stagecraft are virtually ignored. Apart from about 100 brief entries for terms, theater movements, genres, etc., the work consists wholly of entries for playwrights. For each major dramatist there is a biographical sketch, a brief critique of his work, a selection of synopses of his plays, and a bibliography of editions (including references to individual plays published in anthologies) and, usually, a list of critical and biographical works. For the lesser dramatist there is a brief account of his career, achievement, and dramatic output, and occasionally a synopsis of one or more plays. There is an admitted emphasis on English, American, and Western European dramatists. Although there are hundreds of good-quality illustrations, many of them are unsatisfactorily captioned as to date or identity of players, and much of the space expended on close-ups of star performers might better have been devoted to adequate representations of stage settings. For the reference librarian the bibliographies are likely to prove the most valuable feature of this set. -E.S.

Mellown, Elgin W. A Descriptive Catalogue of the Bibliographies of 20th Century British Writers. Troy, N.Y., Whitston, 1972. 446p. \$17.50. 79-183301.

This is an annotated bibliography of bibliographies for British writers born after 1840 , who published most of their work in England or Ireland after 1890. Emphasis is on the humanities and "imaginative" authors, with only the "better-known" scientists and social scientists included. For each author Mellown lists primary bibliographies (the author's work), secondary bibliographies (criticism), and appearances in any of about twenty general sources such as the New Cambridge Bibliography of English Literature, Who's Who, Twayne's American and English author series, etc. Each primary and secondary bibliography is annotated as to scope, arrangement, and critical evaluation. Many bibliographies in progress are noted, but some published supplements have been omitted. Mellown's audience is the student and the general reader, so he has not included some of the more specialized bibliographies (e.g., exhibit catalogs) listed in Howard-Hill's Bibliography of 
British Literary Bibliographies (Suppl. 3BD25). Altogether, this is a clearly presented, generally comprehensive, and useful work.-D.G.

\section{Fine Arts}

McCoy, Garnett. Archives of American Art; a Directory of Resources. N.Y., Bowker, 1972. 163p. \$20.00. 72-5125.

Founded as an independent organization in 1954 and now part of the Smithsonian Institution, the Archives of American Art have become increasingly important as a repository for the documentary evidence of art in America. Papers have been acquired or borrowed from artists, dealers, critics, collectors, curators, and institutions, and they have been microfilmed so that all two million items in the Archives are readily available for use by direct visit to, or interlibrary loan from, one of the five regional centers with duplicate collections in New York City, Washington, Boston, Detroit, and San Francisco.

The purpose of this slim volume is to describe in compact detail the contents of the 555 groups of papers. Arrangement is alphabetical by the key personality or institution with whom the specific collection deals. Information given includes sources of the documents, their form (i.e., letters, notebooks, etc.), quantity, inclusive dates, and the names of major correspondents when appropriate. There is a personal and institutional name index. Since the collections are heavily weighted toward twentieth-century materials, this guide will be of great help to scholars working in the field of modern art where original source materials are still hard to locate. For this reason, regularly published new editions or supplements listing new acquisitions would be welcome.-E.L.

\section{Social ScIEnces}

Driver, Edwin D. World Population Policy: An Annotated Bibliography. With the assistance of Shirnavaz Driver, Shanta Driver, and Cyrus Driver. Lexington, Mass., Lexington Books, [1971]. 1280p. $\$ 30.00$. 73-184302.

The compilers have produced a truly excellent bibliography within the bounds of their definition of population policy: "both direct and indirect measures, formulated and implemented by the whole range of social institutions including government, which, whether intended or not, may influence the size, distribution, or composition of human population."-Pref. They have covered systematically and comprehensively the literature published between 1940 and 1969 in 3,519 entries, most of which are annotated. The work begins with 1940 because D. B. Glass's Population: Policies and Movements in Europe (London, 1967) covers the small body of literature to that time. The author index and an excellent subject index enhance the arrangement which is by major area, component region, and nation, plus a large "interregional" section. Of further help is Driver's prefatory explanation of his method and major bibliographical sources.-M.M.

Gallup, George Horace. The Gallup Poll: Public Opinion, 1935-1971. N.Y., Random House, [1972]. 3v. (23888p.) $\$ 95.00 .77-39867$.

These volumes present a compilation of statistical data from more than 7000 Gallup Poll reports dating from the founding of the poll in October 1935 to December 1971. The polls are the work of the American Institute of Public Opinion, an independent fact-finding organization supported by its subscriber newspapers (which have the exclusive right to publish the Gallup findings). Until now the only finding aids to the published data had been newspaper indexes and the index entitled Gallup Poll Reports, 1935-1968 (Princeton, 1969). which gave only the date of the poll and a very brief summary of the findings. In contrast, this new work contains all of the statistical data released to the subscriber newspapers. The newspaper release date is also given to facilitate location of the editorial and interpretative material which has been omitted from this compilation. The polls are further identified by survey, index and question numbers. A detailed explanation of the sampling and survey procedures can be found in the introductory material; a personal name/subject index is appended. $-B . W$.

Index to Literature on the American Indian, 
1970- . San Francisco, Indian Historian Press, 1972- . Annual. $\$ 12.00$ yr. 70-141292.

Sponsored by the American Indian Historical Society, this is an annual survey of current books, periodical articles, government documents, and doctoral dissertations on the Indians of North, South, and Central America. Arrangement is alphabetical, but authors and anonymous titles are listed separately from subjects. Each volume includes a directory of Indian periodical publications. Editorial work on the 1971 edition shows improvement, but many citations are still not sufficiently cross-listed, and it seems inconsistent to put the Bureau of Indian Affairs under "B" and the rest of the U.S. government agencies under "U." The literature surveyed is American, but the publisher intends to include foreign literature in future editions. Though the compilers emphasize that the Index is selective, it seems fairly comprehensive, and has been enthusiastically welcomed by readers.D.G.

Marxism, Communism and Western Society; a Comparative Encyclopedia. Edited by C. D. Kernig. N.Y., Herder and Herder, [1972- ]. v.1- . (In progress.) $\$ 276.00$ the set. $79-176368$.

Contents: v. 1-4, Absolutism-Judicial system.

What do the Communists believe about genetics? What is the role of banking in the USSR? What is the "German question" to the Germans?-to the Russians? The conflicting answers the East and West give to such questions, the scholars writing in this work feel, are "rooted in incompatible systems of thought" as well as in divergent interests. Thus, this encyclopedia endeavors to cover all areas in which there is disagreement between East and West: biology, economics, history, law, literature, military science, pedagogics, philosophy and ideology, physics, politics and sociology, psychology, and religion. "An international team of scholars and experts, working together over a number of years, has attempted to discover the origins and structure of these conflicts, to analyze why interpretations of these conflicts differ, and to determine the methods adopted in the various approaches."-Pref.
An outline preceding each article shows at a glance how the subject will be treated. Articles often begin with the general theory and history of a term before launching into the Communist interpretation and application; in others, the subject is treated first from one viewpoint and then from the other, followed by a comparison. Most articles are signed (a few were written by the editorial staff), and include full bibliographical references. That they were carefully researched is evidenced by the length and scope of the bibliographies.-M.M.

Public Affairs Information Service. Foreign

Language Index. N.Y., The Service, 1972 - v.1, 1968/71; v.2- , 1972. Quarterly, with annual cumulation. $\$ 100.00$ per yr.

Designed as a counterpart to PAIS Bulletin (Guide CA22), this useful new tool indexes writings on public and economic affairs in the French, German, Italian, Portuguese, and Spanish languages. Emphasis is on factual and statistical material. Volume 1, covering mid-1968 through 1971, includes periodical articles only. The editors intend, however, to produce a quarterly beginning with volume 2, 1972 (the fourth issue being the annual cumulation), and these succeeding volumes are to include a "selective listing of current books, pamphlets, government publications, and other useful library materials in addition to articles in periodicals."-Pref. It is hoped that other languages can also be included in the future.

As in PAIS Bulletin, the arrangement is by subject, but here the individual entry is listed by author rather than title. The author index is a welcome addition. Full citations are provided in the subject section, including notes about summaries in other languages and articles originally prepared as conference papers; entries in the author section are shortened forms of the subject entries. The completeness of information is extended to the periodical key which includes cost and publisher's address as well as full title. This promises to be a very important index for foreign language material in public and economic affairs.-J.S.

Winton, Harry N. M., comp. Publications of the United Nations System; a Refer- 
ence Guide. N.Y., Bowker, [1972]. 202p. $\$ 10.95 .72-4923$.

This welcome reference tool serves as a guide to the numerous publications of the United Nations system. A brief survey of the twenty-two organizations and their publications is provided in the first part; the headquarters address, other principal offices, aims and membership, and the structure of each agency are followed by a list of agency publications, material about the agency, basic instruments and official records. The second part is comprised of selected reference materials arranged by broad subject categories ranging from agriculture to treaties and other international agreements. Title entries are grouped according to type (e.g., statistics, directories, bibliographies, catalogs). Complete citations and detailed annotations are provided.

The last part of the work is a list of periodicals and other selected recurrent items, both subscription and unpriced, published by the United Nations system. Citations include periodicity, availability, first year of issue, language, and a brief subject analysis. Mr. Winton has compiled a handy, useful guide which indicates the scope as well as the number of publications of the U.N. system.-J.S.

\section{Atlases}

The Atlas of the Earth, with a Foreword by Sir Julian Huxley. Tony Loftas, ed. [London], Mitchell Beazley Ltd., [1972]. 303p. il. $39 \mathrm{~cm}$. $\& 13.95$.

The editors of this atlas have a definite and obvious point of view-specifically, a belief in the importance of ecology - which they promote throughout the book. The method of promotion is to provide very short articles surrounded by striking color photographs and illustrations, on topics ranging from the relationship of the earth to the rest of the solar system, to prospecting for minerals, and even including the religions of man. Nearly a third of the volume is taken up with this kind of material which is infused with a great amount of editorializing. Maps comprise only slightly more than one-third of the work (the remaining portion is the index). The maps themselves are reasonably clear, and the projection used is identified in every case. As one might expect with a British atlas, there is extensive and detailed coverage of Great Britain. For each area of the world, however, there are maps showing topography, political divisions, natural vegetation, annual rainfall, climate, and population. Unfortunately, there are no citations to sources, so that, for example, one cannot tell whether 1970 census data are utilized in the population map of the United States. The reference value of this atlas is not significantly increased by the large section devoted to articles, illustrations, and photographs, however attractive they may be: what little factual information they provide can readily be found elsewhere.-D.A.S.

\section{History}

Great Britain. Public Record Office. The Second World War; a Guide to Documents in the Public Record Office. London, HMSO, 1972. 303p. £2.90. (Public Record Office handbooks, no.15) 72 188316.

The Public Records Act of 1967 changed the "closed" period of British public records from fifty to thirty years, permitting the early records of World War II to be opened. Realizing that papers occupying seven miles of shelving could not all be released at one time (as was done with World War I papers), the Public Record Office arranged to make accessible papers of the greatest public interest by early 1972. In conjunction with the general release of papers in early 1972, the office prepared a guide which describes each class of papers in the 1939-1945 war files, indicating the number of pieces in each file and giving one or two sentences of description. The evolution of the internal governmental structure during the war "is described in broad terms .... and these descriptions are expected both to contribute towards comprehension of the records and to signpost the nature of the material to be found."-Introd. Concluding the volume are four helpful appendexes: a dictionary of code names in use during the war; a list of abbreviations used in the Official Histories of the Second World War; a general index to war cabinet committees; and a list of the Official Histories of the Second World War.-E.M. 
Sainty, John Christopher. Treasury Officials, 1660-1870. London, Athlone Pr. for Univ. of London, Institute of Historical Research, 1972. 161p. £4.50. (Officeholders in modern Britain, 1).

The first of a series of lists of officials in the central government in Great Britain from the Restoration to 1870, Treasury Officials sets the pattern for further volumes to be issued-very soon, one hopes. First comes an introduction to the history and the growth of the Treasury from a Treasurer with five assistants in 1660 to over 100 officials in 1870. Then follows a chronological list of appointments arranged by office; a list of Treasury officials at a particular date (coronation or formation of new government); and an alphabetical list of names indicating all the offices held by one individual in the Treasury and the source of the information. The introduction to the chronological list of appointments gives a short survey "which brings together information concerning such matters as method of appointment, remuneration and relevant statutes and Treasury minutes."-Note, p.xiii. A great amount of research went into the compilation of the lists, for, until 1714 when records became more complete, the names are often buried in manuscript lists of accounts and fees. Scholars should be grateful for the aid to research which this project will provide.-E.M.

\section{New Editions aNd Supplements}

The fourth edition of the Totok-Weitzel Handbuch der bibliographischen Nachschlagewerke (Frankfurt am Main, Klostermann, 1972. 367p.; 3d ed., 1966, Suppl. 1AA1) has been updated through 1971. Volume 1, A-E, of the second edition of Donald G. Wing's Short-title Catalogue of Books Printed in England, Scotland, Ireland, Wales, and British America (N.Y., Index Committee of the Modern Language Association of America, 1972) follows the scope and method of the earlier edition (Guide AA504), and, "as far as possible," item numbers remain the same; the number of libraries represented for locations has been increased to more than 300 .

The much-publicized first volume of $A$ Supplement to the Oxford English Dictionary (Oxford, Clarendon Pr., 1972; con- tents: A-G) scarcely needs mention here. Superseding the 1933 supplement (Guide AE21), the three volumes of this new supplement will contain an estimated 50,000 main words. Bringing to the half-way mark the project of indexing forty of the principal monthlies and quarterlies of the period, the second volume of The Wellesley Index to Victorian Periodicals (Toronto, Univ. of Toronto Pr., 1972) indexes twelve periodicals as opposed to eight in v.1 (Suppl. 1AF27). Percy and Grace Ford's useful Guide to Parliamentary Papers (Guide AH52) has appeared in a third edition (Shannon, Irish Univ. Pr., 1972. 87p.).

A supplement (Detroit, Gale, 1972. 852p.) to Robert B. Slocum's Biographical Dictionaries and Related Works (Suppl. 2AJ1) contains approximately 3,400 additional entries, with some new editions and corrections noted. Biographical sketches of 573 significant figures who died during the 1941-45 period are included in the Dictionary of American Biography, Supplement Three (N.Y., Scribner's, 1973. 879p.). The volume was edited by Edward T. James, has signed contributions by 475 scholars, and includes a consolidated list of the biographies in all three supplements. A sixth volume (London, Black, 1972. 1243p.) in the Who Was Who series includes biographies of persons who died in the years 1961-1970, with an addenda of sketches of some who died before the end of 1960 but who were omitted from the 1951-60 volume (Guide AJ152). Inasmuch as the Dictionary of South African Biography (Suppl. 3AJ36) is not governed by any overall chronological or alphabetical sequence, the second volume (Pretoria, Nasionale Boekhandel Bpk., 1972. 870p.) presents sketches of another diverse group of personalities from all periods of South African history.

Compiled by James D. Pearson and Ann Walsh, the third supplement to Index Islamicus (London, Mansell, 1972. 384p.) contains about 8,000 entries for the 196670 period. Mansell has also announced a reprint of the basic volume of the Index (Guide BB264) and plans for annual supplements covering 1971 through 1974 , with a quinquennial cumulation for 1971-75. 
Medieval Religious Houses, England and Wales (N.Y., St. Martin's Pr., 1972. 565p.), by David Knowles and Richard N. Hadcock, is a revised, expanded and corrected edition of their 1953 volume of the same title (Guide BB244).

The English Romantic Poets, previously edited by Thomas M. Raysor (Guide BD394), appears in a third edition under the editorship of Frank Jordan (N.Y., Modern Language Association of America, 1972. 468p.). This useful survey of research has been updated to cover publications through 1970 , with a few early 1971 items included. The period of coverage in Reginald E. Watters's Checklist of Canadian Literature and Background Materials (Guide BD301) has been extended through 1960 in a revised and considerably enlarged edition (Toronto, Univ. of Toronto Pr., 1972. 1085p.). Carl J. Stratman's Bibliography of Medieval Drama (Guide BD134) has appeared in a second edition (N.Y., Ungar, 1972. 2v.) The work has been greatly expanded, with the addition of about 5,000 entries, some rearrangement of the sections, and increased emphasis on the liturgical Latin drama.

An aid for political scientists, sociologists, and economists, the second edition of the World Handbook of Political and Social Indicators by Charles L. Taylor and Michael C. Hudson (New Haven, Yale Univ. Pr., 1972. 443p.) follows closely the format of the 1964 edition by Bruce M. Russett. This "attempt to compare nations on a great variety of politically relevant indices" is presented mainly in tabular form, with introductory and explanatory text.

A welcome supplement to Warren F. Kuehl's Dissertations in History has been designated as "volume 2" of the work (Lexington, Univ. of Kentucky Pr., 1972. 237p.). It lists about 5,900 dissertations completed in history departments during the 1961-June 1970 period. Some dissertations accepted earlier, but omitted from the 1873-1960 volume (Suppl. 1DA4) are also included.-E.S. 